IRSH 55 (2010), pp. 365-372 doi:10.1017/S002085901000030I

(C) 2010 Internationaal Instituut voor Sociale Geschiedenis

\title{
GUIDE TO THE INTERNATIONAL ARCHIVES AND COLLECTIONS AT THE IISH: SUPPLEMENT OVER 2009*
}

In 2000 a new edition of the 'Guide to the International Archives and Collections at the IISH, Amsterdam' (henceforth cited as GIA) was published. A description of recently acquired archives and collections as well as major accruals to archives received by the IISH is published annually to keep this survey up to date. Like the GIA this supplement is subdivided into the categories 'persons', 'organizations', and 'subjects', arranged alphabetically.

As to the summaries the following components can be discerned:

I. Access: As a rule consultation is not restricted; any restrictions are indicated by*.

2. Name: Names of persons include dates of birth and death when known. In the case of international organizations with names in more than one language, the name chosen corresponds to the language in which most of the documents were written. Among organizations that have changed their names, the one used most recently has been selected. Previous names of organizations are mentioned in the condensed biography or history. The names of subject collections are mostly in English.

3. Period: First and last date of the documents present. Where only a few documents are from a certain year or period, they are listed between parentheses.

4. Size: In linear metres.

5. Finding aid: Available inventories, lists, and indexes.

6. Biography/history: A condensed biography or history of the persons or organizations concerned.

7. Summary of the contents: A summary of the contents of the archives, papers, or collection concerned.

Reference is given to the pages of the GIA holding the initial description where summaries of an accrual are concerned.

The summaries of this supplement will also be added to the survey of archival collections on the Internet website of the IISH (http://www.iisg.nl). Summaries of the Dutch collections of the IISH can be found in the survey on the Internet website too.

The archives may be consulted in the reading room of the IISH. Requests for documents should include their inventory or list numbers. For further information about the rules for access and consultation (including rules on procedures for handling the material and making photocopies) users should contact the information service of the IISH (e-mail: ask@iisg.nl).

* Edited by Bouwe Hijma 


\section{Persons}

\section{Avot-Meyers, Pierre (1930-2009) \\ Period: 1943-1992 \\ Size: $1.62 \mathrm{~m}$.}

Born in Paris 1930, died in Nanterre, Hauts de Seine 2009; member of the Confédération Générale du Travail (CGT) I948; worked in the Chausson car factories in Gennevilliers 1949; military service 1950-1952; worked in printing office in Meudon and again in the car factories in Gennevilliers; CGT employees' representative 1954-1958; member of the Parti Communiste Internationaliste (Trotskyist) since 1949; participated in youth brigades in Yugoslavia 1950; supporter of the Front de Libération Nationale (FLN) during the Algerian War of Independence; fled after the discovery of the clandestine printing office of the Fourth International in Paris to Italy 1960; lived in Algeria after its independence in 1962 as a collaborator of the FLN journal El Moudjahid; was arrested in 1965 after the coup of Houari Boumédiene and expelled to France three weeks later; worked as corrector at the publishing house of Canard enchaine in Paris; sided with Pablo (Michel Raptis) in the discussion which split up the Fourth International in 1965 and subsequently joined the International Revolutionary-Marxist Tendency.

Bulletins, tracts and other documents of the Fourth International (France) 1940-1948; educational materials of the Parti Communiste Internationaliste (PCI) I948-I959; circulars, reports and other documents of the International Revolutionary-Marxist Tendency/Tendance Marxiste-Révolutionnaire Internationale (TMRI) I964-I992; bulletins, pamphlets and other documents of the Front de Libération Nationale (FLN) in France and of several relief committees concerning the Algerian War of Independence 1956-1978; documents concerning Ben Bella 1965-1978; documents concerning the criminal trial in Amsterdam versus Michel Raptis and Sal Santen, with some letters from prison by Michael Raptis 1960-1963; the Bulletin Intérieur of the PCI 1943-1965; photocopies of typescripts 'Un procès exemplaire. Algérie 1952. Récit autobiographique' by Jean Jaffré 2003 and 'Algies' by Sid'Ali Boulaloua n.d.; some documentation.

\section{Axa, Zo d' (1864-1930) \\ Period: I878-1923 (1968) \\ Size: $0.06 \mathrm{~m}$.}

Born as Alphonse Gallaud de la Pérouse in Paris 1864, died in Marseille 1930; son of a wealthy engineer, adventurer, traveller, anti-militarist, individualist, satirist, journalist, founder of two of the most legendary French magazines of the I890s, L'En Dehors (1891-1893) and La Feville (I 897-I 899); deserted from the French cavalry to Belgium and went into exile in Italy i 889; ran an ultra-Catholic newspaper; accused of insulting the Empress of Germany and the French army and became an anarchist due to the subsequent legal proceedings against him; returned to France taking advantage of a general amnesty; confessed more strongly to anarchism and founded the anarchist newspaper L'EnDehors I89I; target of the authorities and kept in jail in Mazas Prison in Paris; wrote numerous pamphlets after his release; once more arrested in Italy but released 1894; published De Mazas à Jérusalem with illustrations by Lucien Pisarro, Steinlen and Félix Valloton I895; travelled to Mexico, Canada, and the United States; committed suicide in Marseille 1930.

Photocopies: youth writings I 878; letters by Alexandre Cohen I 895, Lucien Descaves I 892 and n.d., Félix Fénéon I892-I897 and n.d., Augustin Hamon 1895-1896, Henry Kistemaekers I894 and n.d., Errico Malatesta I923, Théophile-Alexandre Steinlen n.d., 
Adolphe Tabarant n.d. and others; documents on the affair Lécuyer I889-1894; documents on the trial on the accusation of insulting the army I893-I898; letters by Hem Day 1968.

\section{Bachriadi, Dianto (born 1965) \\ Period: 1994-2005 \\ Size: $0.37 \mathrm{~m}$.}

Born in Lakat, Sumatra, Indonesia 1965; grew up in Jakarta; undergraduate degree in anthropology from the University of Bandung, Indonesia, Ph.D. student of Flinders University, South Australia, Luce fellow Institute of International Studies University of California, Berkeley 2005-2006; executive director of Pergerakan (People Centred Advocacy Institute), member of the national team for the working group on agrarian conflict resolution under the Indonesian government's national committee on human rights (KOMNAS HAM); chairperson of the executive body of the Consortium for Agrarian Reform (CAR)/Konsorsium Pembaruan Agraria (KPA) in Indonesia.

Papers and reports published by the Konsorsium Pembaruan Agraria (KPA) on congresses and agricultural themes I994-2005.

\section{Bakker Schut, Pieter Herman (1941-2007) \\ Period: $1975^{-1977}$ \\ Size: $2 \mathrm{~m}$. \\ Finding aid: list}

Born in Haarlem I94 I, died in Amsterdam 2007; after law studies in Leiden, became a well-known law teacher, law critic, and lawyer; defended in controversial court cases students who had occupied the Maagdenhuis, the administrative centre of Amsterdam University, and Lucien van Hoesel, an early member of Holland's Red Youth; one of the instigators of the so-called Sociale Advocatuur, a subsidized network of lawyers providing legal aid for a small fee, and one of the founders of the Coornhert-Liga, an organization advocating numerous legal reforms; while teaching at the Willem Pompe Institute in Utrecht, moderated a prestigious television series on law, 'Kort Geding'; shared several law offices with his wife Adèle van der Plas and other 'political' lawyers such as Ties d'Oliveira-Prakken; for a period of 30 years defended prisoners from the German Rote Armee Fraktion (RAF) and their struggles in prison; lawyer of RAF-members Ronald Augustin, Andreas Baader, and Heidi Schulz; one of the founders of the Medisch-Juridisch Comite Politieke Gevangenen; also defended the German lawyer Klaus Croissant, one of the attorneys in lawsuits against the RAF, in several legal procedures; during the last years of his life involved in famous Dutch court cases such as those against arms trader Mink Kok and the Kurdish businessman Hüseyin Baybasin; obtained his Ph.D. with a case study on the trial against the RAF in Stuttgart-Stammheim, which has become the standard work on political trials in Germany during the 1970s: Stammbeim: Der Prozess gegen die Rote Armee Fraktion; Die notwendige Korrektur der herrschenden Meinung 1986.

Documents on the Rote Armee Fraktion: copies of minutes, records and verdict of the trial against Andreas Baader, Gudrun Ensslin, Ulrike Meinhoff, and Jan-Carl Raspe, Stuttgart-Stammheim, 2 I May 1975-28 April 1977.

Cauer, Minna (I84I-I922)

Period: I868-1922 (-2009)

Size: $0.87 \mathrm{~m}$. 


\section{Finding aid: inventory}

Accrual: for initial description see GIA, pp. 56-57.

Gabriele Braun-Schwarzenstein: correspondence with Karoline Cauer 1977-1986, Wolfgang Mommsen 1977-198 I, Lilly Somerhausen-von Stoffregen 1978-1985 and others; typescripts and notes on Minna Cauer 1968, I982 and n.d.; transcripts of diaries, letters and manuscripts of Minna Cauer I868-1922; documentation on Minna Cauer and the women's movement c.I892-1998;

Lilly von Stoffregen: correspondence I924-1927, I947, I 984 and n.d.; typescript on Minna Cauer i982;

Muschka von Witt: correspondence with Minna Cauer and others I892-I922.

\section{Clarke, Simon (born 1946)}

Period: 1989-1998

Size: $0.37 \mathrm{~m}$.

Simon Richard Curtis Clarke; born in London 1946; Professor of Sociology, University of Warwick, Great Britain; directed the Russian Research Programme in the Department of Sociology; his research and projects focused on the restructuring of the coal-mining industry, the development of independent trade unions in Russia, household survival strategies and new forms of employment, and on changing gender relations and gender identity.

Documents on trade unions, strikes and other aspects of the Russian workers' movement in the early I990s I989-1998.

\section{Danneberg, Robert (1885-1942) \\ Period: (I88I-) 1938-1946 (-I992) \\ Size: $0.2 \mathrm{~m}$. \\ Finding aid: inventory \\ Accrual: for initial description see GIA, p. 65 .}

Correspondence by Gertrude Danneberg-Schröbler, wife of Robert Danneberg, with her son Karl Danneberg 1939-1945, her daughter Lieselotte Danneberg I94I-1945, Robert Danneberg 1934-1939, Ferdinanda Flossmann 1938-1939, Red Cross Message Bureau I94I-I 942, Dora and F. Schröbler I938-I943; correspondence by family members of Gertrude and Robert Danneberg I88 I-I943.

\section{Dikerdem, Mehmet Ali (born 1949)}

Period: $1977-1980$

Size: $0.75 \mathrm{~m}$.

Born in Ankara, Turkey 1949; social scientist who has taught Development Studies, Race and Ethnic Relations and Social Policy since the mid-I980s; principal learning tutor at Middlesex University, London; got his Ph.D. at Sussex University, Brighton with a study Factory and workshop. An investigation into forms of small-scale production in Turkey, on the role of small and medium business companies in the city of Bursa 1980. 
Mainly survey forms about the metalworking factories and small-scale workshops in Bursa and Gaziantep, Turkey, which were used for his Ph.D. thesis, typescript of his Ph.D. thesis, some notebooks and other documents 1977-1980.

\section{Gasió, Guillermo (born 195I) \\ Period: $1989-2000$ \\ Size: $0.12 \mathrm{~m}$.}

Born in Buenos Aires 195 I; graduated as a lawyer University of Buenos Aires 1974; Argentinian diplomat; came to the Netherlands as a member of Argentina's Foreign Service April 1989; did research for his study on the collapse of 'real existing socialism' in Amsterdam, Berlin, and at Harvard University; interviewed politicians who played an important role during this transformation process in the German Democratic Republic, Hungary, Poland, and Czechoslovakia.

Typescript 'Comrades at Twilight' by Guillermo Gasió (Amsterdam, Berlin, Buenos Aires, Cambridge 1989-2000); typescripts, with corrections by the interviewed politicians, of his interviews with Miloš Jakes, Miroslav Štepán, and Karel Urbánek (Czechoslovakia), Egon Krenz, Hans Modrow, and Günter Schabowski (Germany), Károly Grósz, Gyula Horn, and Rezsö Nyers (Hungary), and Wojciech Jaruzelski, Stanislas Kania, and Mieczyslaw Rakowski (Poland) 1992.

\section{Rosenstrauch, Hazel Elfriede (born 1945) \\ Period: $1967-1971$ \\ Size: $0.05 \mathrm{~m}$.}

Born in London 1945; grew up in Vienna; went to the United States and Canada and studied in the I96os in Berlin; Ph.D. in Tübingen on Buchhandelsmanufaktur und Aufklärung 1986; worked as a journalist, editor, university teacher in Berlin, Vienna, Tübingen; her main subjects are Enlightment, biographies around $\mathrm{I} 800$, anti- and philo-semitism and public understanding of science and cultural policy.

Documents on a trial started by Elfriede Rosenstrauch because of the illegal use of weapons by the West Berlin police without permission of the Allies in the killing of the young student Benno Ohnesorg on 2 June 1967 during a demonstration against the visit of the Shah of Iran 1967-1971.

Umar Said, A. (born 1928)

Period: $1979-2002$

Size: $0.05 \mathrm{~m}$.

Born in Pakis near Tumpang, East Java, Indonesia 1928; journalist working for the newspapers Indonesia Raya 1950-1953, Harian Rakyat 1953-1956, Harian Penerangan 1956-1960 and Ekonomi Nasional 1960-1965; officer of the Jakarta-based secretariat of the Association of Asian and African Journalists (PWAA) and treasurer of the central office of the Association of Indonesian Journalists (PWI) 1963-1965; abroad during the coup d'état by Suharto 1965; lived in Chile, Algeria, and Paris but stayed in Beijing as the secretariat of the PWAA moved to Beijing 1965-1973; left for Paris and found a job at the Ministry of Agriculture 1975-1982; also active in the French Tapol Committee from 1974; co-founded restaurant 'Indonesia', run by the cooperative 
SCOP Fraternité, in 1982; editor and later owner of Chine Express (from 1986) and Business with China (from 1992), both issued by his firm China Documentation \& Communication.

Copy of the typescript (originally written in 1995) of the memories of Umar Said 'The journey of my life' [2002]; copies of correspondence and newspaper articles on restaurant 'Indonesia' in Paris, co-founded by Umar Said I979-I986.

\section{Western, Richard W. (I866-1949) \\ Period: I 887-I 949 \\ Size: $3.5 \mathrm{~m}$. \\ Finding aid: preliminary list}

Richard Walsingham Western; pseudonym: I.C. Isbyam; born c.r866, died in Bath, Great Britain 1949; engineer in the Public Works Department in the British Raj and philosopher; published Graphic Chronology, presenting a page for each quarter of a century from 650 B.C. to I 850 A.D., in I 892; some of his later books about new physics were published by C.W. Daniels \& Co. in the late I920s; best known is Metaphysics and Modern Research; said to touch on themes, particularly about relativity, that were not explored until the r980s and r990s; Daniels wrote and published a short précis of Western's work called 'Freedom from inward conflict', showing Western's philosophical and psychological interpretation of Einstein's thinking; chairman of the London Branch of the Association of Scientific Workers; member of one of the Labour Party clubs; committed suicide on 30 June 1949.

Diaries I93 I-I949; correspondence I944-1949; documents on his study years I 887; notes, manuscripts, typescripts, documents regarding his various publications and correspondence with publishers I 892-1949; documents concerning the Association of Scientific Workers 1934-1936, the Authors' Club and the Aristotelian Society.

\section{Wiradi, Gunawan (born 1934) \\ Period: 1959-200I \\ Size: $0.12 \mathrm{~m}$.}

Born in Solo, Java, Indonesia 1934; researcher, activist for agrarian and land reform in Indonesia and consultant for various NGOs; studied agricultural policy and rural sociology at the Institut Pertanian Bogor (Bogor University of Agriculture) I953-1963; teacher at the Faculty of Animal Husbandry 1963-1972; worked in Bogor as a researcher for the Agro-Economic Survey from 1972 until the r 980 and published on themes of rural development.

Agenda 1974, I990, 200I; notebooks 1974, I979, I982-1984, I986; correspondence 1974, I982-1984; other documents 1959, I961, I968.

\section{Organizations}

\section{CNT (France). 2 me Union régionale}

\section{Period: I914-1996}

\section{Size: $1.87 \mathrm{~m}$.}

The Confédération Nationale du Travail (CNT-France) was founded in Paris 1946 by Spanish anarcho-syndicalists in exile and former members of other French organizations; associated with 
the Association Internationale des Travailleurs (AIT); about 16 syndicates were linked to it; the history of the 2 me UR was characterized by numerous conflicts between followers of syndicalism and anarchism, symbolized by Julien Toublet and Raymond Beaulaton; since the end of the I970s the position of the 2me UR was marginal; it joined the 1993-founded CNT-AIT 2006.

Correspondence, minutes, circulars, bulletins and other documents concerning the secretariat 1946-1965, 1972 and n.d.; cashbooks and other documents on the finances and the administration 1946-1953, 1960-1968, I971-1996; correspondence and other documents concerning Le combat syndicaliste and Action directe 1948-1960, 1967, I97I-I972; correspondence, bulletins, tracts and other documents concerning the Jeunesses Anarcho-Syndicalistes and the Jeunesses Syndicalistes I914-I9I5, I922-I924, I969 and n.d.; circulars, reports and other documents concerning the CNT-France and the AIT I938, I947-1955, I960, I967, I97I-1976 and n.d.; minutes of the conferences of the AIT 1953, 1956, I958, I967, I971, 1976; documents concerning the internal conflict 1975-1985; documents concerning the lawsuit against the owner of the office 1975-1991; the Bulletin d'information I98I-1986; some documentation.

Part of the archive contains the papers of José Soriano, secretary of the organization, including his personal papers 1963-I97I and n.d.; general correspondence of the organization 1945-1973; correspondence from and to Le combat syndicaliste 1952-1960; correspondence from and to L'action syndicaliste 1945-1946; minutes and other documents concerning the conferences of the confederation I956-1970; various documents I945-I97I.

\author{
*Communist Party of the Philippines \\ Period: 198 I-I989 \\ Size $0.25 \mathrm{~m}$. \\ Finding aid: list
}

The Communist Party of the Philippines (CPP) (Partido Komunista Pilipinas) was founded by José Maria Sison on 26 December 1968; the CPP is ideologically Maoist and fought a protracted people's war through its armed wing, the New People's Army since 1969; heads the broad revolutionary front organization, the National Democratic Front; Sison is living in The Netherlands since his release from prison 1987.

Evaluations, papers, programmes, publications, statements and other documents by and on the Communist Party of the Philippines (CPP) and especially documents on the International Solidarity Work by the CPP in Japan and the Asia-Pacific Committee (ASPAC) of the CPP I98I-I989.

\title{
*DHKP/C (Revolutionary People's Liberation Party), letters from revolutionary captives \\ Period: (1996-1997) 1998-2007 (2008) \\ Size: $7 \mathrm{~m}$.
}

Finding aid: inventory

The DHKP-C (Devrimci Halk Kurtulus Partisi/Cephesi/Revolutionary Peoples' Liberation Party) founded in 1978 as a splinter group of the THKP-Cf; at first the new movement 
called itself 'Revolutionary Left' (Dev-Sol) but changed its name in 1994 to DHKP-C; the party follows an 'independent revolutionary' course aimed at establishing a 'socialist society in the interests of workers and all sections of the population in Turkey'; since the party was founded, many of its militants have spent shorter or longer periods in prison; they played an important role in the struggle against the prison regime in Turkey; prisoners in Turkey are usually held in large dormitories, some accommodating more than 60 detainees at a time; in 1995 the government started adding new wings to the I I existing prisons; designed according to the 'cellular principle' and referred to as 'Type F', these new prison blocks have been in use since the year 2000; prisoners, prisoner's relatives, human rights activists and representatives of civil organizations feared for a greater risk of abuse or torture under the new maximum security prison system; the deployment of Type-F cell blocks was accompanied by a wave of protest and demonstrations inside the prisons which was brutally suppressed; from October 2000 to April 2006 more than I,000 prisoners went on hunger strike in protest; on 22 April 2006 Fatma Koyupinar starved as the I 22nd person on hunger strike; the Turkish authorities reduced the severity of the prison regulations on 22 January 2007 as a concession to the objections raised against solitary confinement in Type-F prisons.

Correspondence by captives from Ankara Sincan, Edirne, Kocaeli Kandira, Kartal, Tekirdag and other prisons I998-2007; correspondence between captives and sister organizations of the DHKP-C 2000-2006; correspondence by and documents on martyred militants 1997-2005; documents on death fasts 2000-2004; also some handwritten monographs and periodicals, writings, articles, and poems which often accompanied the letters or were sent as letters I996-2008.

\section{Subjects}

Letters from the representatives of the Iranian authorities in the Soviet Union on Iranian Immigrants

Period: $1927-1939$

Size: $0.25 \mathrm{~m}$.

Iran and the former Soviet Union shared a border stretching for 2,643 kilometres; at both sides of the border were people with a common history, language, and religion; at the end of the 19 th and the beginning of the 2oth centuries Iranian labourers emigrated to the Caucasus region where the economy was booming; emigration continued after the October Revolution of I9I7 raised the Bolsheviks to power in Russia and during the Pahlavi monarchy in Iran (since 1926 due to high unemployment rates in Iran), but some migrant workers returned to Iran where they were faced with enduring unemployment.

Photocopies of official letters from the representatives of the Iranian authorities in the Soviet Union on Iranian Immigrants 1927-1939. 